\section{JURNAL ABDIMAS

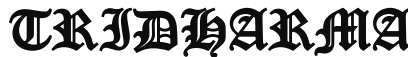

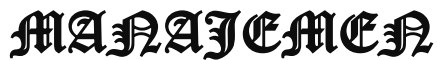

P-ISSN 2615-6849, E-ISSN 2716-070X

Jurnal ABDIMAS Vol.3,No.1,Desember 2021,Hal(105109)

@ Prodi Manajemen Fakultas Ekonomi Universitas Pamulang

Email: abdimasjurnal.unpam@ gmail.com Telp: (021) 741-2566

\title{
MEMBANGUN PONDASI AWAL TAMAN BACA GUNA MENCERDASKAN MASYARAKAT BERSAMA KOMUNITAS ARIMBI DI LINGKUNGAN RT 05/01 DESA PONDOK PUCUNG KECAMATAN PONDOK AREN.TANGERANG SELATAN
}

\author{
Abdul Rahman Safiih, Asep Suherman, Imbron, Hafis Laksmana Nuraldy,Muhammad Abid \\ Dosen Fakultas Ekonomi Bisnis Universitas Pamulang \\ Email : dosen02457@unpam.ac.id, \\ dosen02438@unpam.ac.id, dosen02455@unpam.ac.id, \\ dosen02460@unpam.ac.id, dosen02466@unpam.ac.id,
}

\begin{abstract}
ABSTRAK
Kegiatan pegabdian kepada masyarakat ini bertujuan untuk Membangkitkan dan meningkatkan minat baca masyarakat sehingga tercipta masyarakat yang cerdas dan selalu mengikuti perkembangan ilmu pengetahuan dan teknologi.

Metode yang akan digunakan dalam pengabdian masyarakat ini adalah melalui kegiatan pendampingan dan sosialisasi membangun taman baca dilingkungan Desa Pondok Pucung Kecamatan Pondok Aren. Tangerang Selatan. Sebelum dilakukannya PKM Tim PKM melakukan wawancara atau survei langsung ke subyek pengabdian dengan cara memberikan pertanyaan langsung atau berbicara secara lisan dengan ketua komunitas Arimbi dilingkungan Desa Pondok Pucung Kecamatan Pondok Aren. Tangerang Selatan. Selain wawancara, tim PKM juga melakukan observasi yang merupakan kegiatan pengamatan langsung di lokasi. Observasi ini dilakukan langsung ke subyek dengan cara pengamatan di lingkungan.

Hasil pengabdian masyarakat adalah membuat taman baca untuk meningkatkan kesadaran literasi sejak dini. Metode yang digunakan adalah 1) Persiapan, 2) Pembuatan Taman Baca, 3) Pelatihan pengurus taman baca, 4) Evaluasi rencana tindak lanjut, 5) Sosialisasi,. Hasil kegiatan: (a) Pembuatan taman baca untuk meningkatkan literasi sejak dini dilingkungan Desa Pondok Pucung Kecamatan Pondok Aren. Tangerang Selatan
\end{abstract}

Kata Kunci: Sosialisasi, taman, baca

\begin{abstract}
ABSTRAC
This community service activity aims to generate and increase public interest in reading so as to create an intelligent society and always follow the development of science and technology.

The method that will be used in this community service is through mentoring and socialization activities to build a reading garden in the Pondok Pucung Village, Pondok Aren District. South Tangerang. Prior to the PKM, the PKM Team conducted interviews or direct surveys to the subjects of service by asking direct questions or speaking verbally with the head of the Arimbi community in the Pondok Pucung Village, Pondok Aren District. South Tangerang. In addition to interviews, the PKM team also conducted observations which were direct observation activities at the location. This observation is carried out directly to the subject by means of observations in the environment.

The result of community service is to create a reading garden to increase literacy awareness from an early age. The methods used are 1) Preparation, 2) Making a Reading Garden, 3) Training for reading garden administrators, 4) Evaluation of follow-up plans, 5) Socialization. The results of the activity: (a) The creation of a reading garden based on local culture has been able to
\end{abstract}




\section{JURNAL ABDIMAS

increase literacy from an early age in the Pondok Pucung Village, Pondok Aren District. South Tangerang

\section{Keywords: Socialization, garden, reading}

\section{PENDAHULUAN}

Seiring dengan perkembangan waktu dan perkembangan jaman yang terus melesat bahwa setiap bangsa harus memiliki generasi emas yang berintelktual dalam hal sumber daya manusia yang mapan akan ilmu dan teknologi untuk dapat bersaing dan mencedaskan kehidupan bangsa, untuk itu diperlukan suatu upaya dilakukan pendidikan baik secara formal dan non formal yang dapat dilakukan dimana saja dan kapan saja. Pendidikan merupakan salah satu kebutuhan dasar dari setiap orang di dunia ini. Pendidikan merupakan proses pembelajaran yang sudah menjadi kebutuhan primer yang artinya pendidikan harus terpenuhi. Dengan adanya pendidikan suatu negara bisa maju dan meningkat. Sebab pendidikan menjadi tonggak kemajuan sebuah bangsa. Oleh karenanya suatu bangsa bisa dikatakan maju jika pendidikannya terkelola dengan baik dan mampu melahirkan bibit-bibit cerdas yang bisa mengembangkan bangsa dan negaranya sendiri. Jika sebuah negara mempunyai pendidikan yang cacat atau banyak permasalahan, maka hal tersebut harus segera diselesaikan supaya tidak menimbulkan permasalahan diberbagai hal. Penelitian mengenai minat baca yang dipublikasikan oleh Central Connecticut State University pada Maret 2016 lalu memang cukup mengejutkan. Laporan mengenai minat baca sejumlah negara di dunia mengungkapkan bahwa minat baca orang Indonesia berada pada urutan 60 dari 61 negara. Sejak itu, upaya untuk meningkatkan minat baca gencar dilakukan banyak pihak untuk menghidupkan semangat literasi masyarakat. Sedangkan permasalahan lain pendidikan yang ada Indonesia diantaranya : ( Kurangnya ketersediaan dana Pendidikan, Tidak tersedianya fasilitas yang memadai, Minimnya bahan belajar mengajar, Kekurangan

jumlah guru yang berkualitas)

Menyikapi permasalahan diatas bahwa masyarakat pada lingkungan desa pondok pucung memiliki permasalahan yang hampir sama dimana yang terjadi dilingkungan RT05/RW01 saat ini diantaranya yaitu maraknya perbuatan prostitusi yang dilakukan oleh para pendatang atau yang ngontrak drumah petakan rata rata dari mereka memiliki status janda dan memilih mencari uang dengan tidak halal tentu hal ini sangat meresahkan masyarakat. Kemudian permasalahan selanjutnya kesadaran minat belajar atau baca yang sangat minim dilakukan oleh anak anak sekolah dilingkungan desa pondok pucung hal ini dapat dilihat dari capaian prestasi belajar yang sangat minim serta para pelajar dan anak anak sekolah lebih asik bermain game, nongkrong tidak jelas sehingga ini akan berdampak terhadap kemajuan desa tersebut karena generasi hebat itu adalah yang mewariskan ilmu tanpa batas dan dapat berguna untuk orang lain. Kemudian permasalahan berikutnya tidak ada tempat fasilitas umum yang dapat menunjang kegiatan yang positif salah satunya untuk belajar bagi warga kususnya anak anak sekolah serta memberikan perhatian khusus pada generasi muda mudi yang ada dilingkungan tersebut agar memiliki tempat kegiatan yang positif. Oleh sebab itu masyarakata setempat meinginkan sebuah tempat yang produktif, mudah diakses, gratis serta beredukasi untuk melakukan kegiatan belajar mengajar bagi mereka yang kurang mampu agar mereka tetap mendapatkan pendidikan yang layak dan hal ini juga sangat bermanfaat bagi masayarakat setempat kususnya untuk anak anak yang masih sekolah. Dengan dibangunnya tempat tersebut hal ini juga sebagai tanda memerangi kegiatan prostitusi yang dilakukan oleh orang-orang yang mencari uang dengan cara yang salah dan tidak halal, sehingga hal ini akan memberikan dampak yang positif dan memberikan tekanan 


\section{JURNAL ABDIMAS

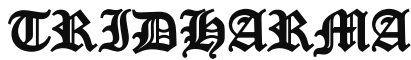 AAA}

P-ISSN 2615-6849, E-ISSN 2716-070X

Jurnal ABDIMAS Vol.3,No.1,Desember 2021,Hal(105109)

@Prodi Manajemen Fakultas Ekonomi Universitas Pamulang

Email: abdimasjurnal.unpam@ gmail.com Telp: (021) 741-2566 dari kegiatan yang bersifat negatif yang ada dilingkungan desa pondok pucung tersebut.

\section{RUMUSAN MASALAH}

Berdasarkan latar belakang masalah di atas, maka dapat dirumuskan permasalahannya yaitu Membangkitkan dan meningkatkan minat baca masyarakat sehingga tercipta masyarakat yang cerdas dan selalu mengikuti perkembangan ilmu pengetahuan dan teknologi.?

\section{TUJUAN PELAKSANAAN}

1. Mensosialisasikan kepada masyarakat guna membangkitkan dan meningkatkan minat baca.

2. Membangun tempat taman baca di lingkungan .

\section{TINJAUAN PUSTAKA}

Salah satu program pembangunan Pendidikan adalah Program pengembangan Budaya Baca dan Perpustakaan. Program ini bertujuan untuk mendorong terwujudnya masyarakat pembelajar sepanjang hayat melalui peningkatan budaya baca serta penyediaan, bahan bacaan yang berguna bagi aksarawan baru, maupun anggota masyarakat pada umumnya yang membutuhkan untuk, memperluas pengetahuan dan keterampilan demi peningkatan wawasan serta produktivitas masyarakat. Taman Bacaan Masyarakat sebagai medium pengembangan budaya baca merupakan tempat mengakses berbagai bahan bacaan: seperti buku pelajaran, buku keterampilan praktis, buku pengetahuan, buku keagamaan, buku hiburan, karya-karya sastra serta bahan bacaan lainnya yang sesuai dengan kondisi obyektif dan kebutuhan masyarakat sekitar dan minat baca baik bagi aksarawan baru, peserta didik jalur pendidikan formal dan non-formal (warga belajar), dan masyarakat umum tanpa batas usia. Taman bacaan masyarakat adalah untuk melayani kepentingan penduduk yang tinggal disekitarnya. Mereka terdiri atas semua lapisan masyarakat tanpa membedakan latar belakang sosial, ekonomi, budaya, agama, adatistiadat, tingkat pendidikan, umur dan lain sebagainya. Sebuah perpustakaan apapun jenisnya didirikan dengan tujuan utama untuk mengumpulkan semua sumber informasi dalam berbagai bentuk, baik informasi tertulis (printed matter), terekam (recorded matter) atau dalam bentuk lain. Kemudian semua informasi tersebut diproses, dikemas, dan disusun sedemikian rupa untuk disajikan kepada masyarakat pemakai yang diharapkan menjadi sasaran dari perpustakaan tersebut. Pada prinsipnya pengertian Taman Bacaan Masyarakat hampir sama dengan pengertian perpustakaan pada umumnya. Karena kegiatan utama TBM juga adalah mengumpulkan, mengolah, dan menyebarluaskan berbagai macam informasi yang berguna bagi masyarakat, khususnya bagi masyarakat yang tinggal di sekitar TBM tersebut. Pengertian Taman Bacaan oleh beberapa ahli yaitu : Pada Buku Pedoman Penyelenggaraan Taman Bacaan Masyarakat (2006,09) Taman Bacaan Masyarakat adalah sebuah tempat / wadah yang didirikan dan dikelola baik masyarakat maupun pemerintah untuk memberikan akses layanan bahan bacaan bagi masyarakat sekitar sebagai sarana pembelajaran seumur hidup dalam rangka peningkatan kualitas hidup masyarakat di sekitar TBM.

\section{HASIL DAN PEMBAHASAN}

Kegiatan ini berkerjasama dengan komuitas Arimbi di Lingkungan RT05/RW01 Desa Pondok Pucung Kecamatan Pondok Aren. Tangerang Selatan. Selama pelaksanaan kegiatan pengabdian ini yang berlangsung di bulan November 2021, warga masyarakat sangat antusias dan merespon baik dengan kegiatan yang kami laksanakan. Adapun hasil kegiatan yang dicapai dalam kegiatan pengabdian ini adalah: 1. Ketua dan komunitas Arimbi mengobservasi lokasi pembuatan taman baca, untuk mengetahui apa saja alat dan bahan yang dibutuhkan dalam pembuatan taman baca. 2. Pelatihan dan sosialisasi untuk pengurusan taman baca, 3. Evaluasi dan rencana tidak lanjut, 4. tujuan akhir dari pembuatan taman baca. Sebelum dilakukannya PKM Tim PKM melakukan wawancara atau survei langsung 


\section{JURNAL ABDIMAS

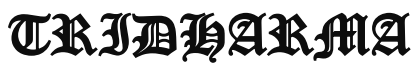 AtA:}

\section{P-ISSN 2615-6849, E-ISSN 2716-070X}

Jurnal ABDIMAS Vol.3,No.1,Desember 2021,Hal(105109)

@ Prodi Manajemen Fakultas Ekonomi Universitas Pamulang

Email: abdimasjurnal.unpam@gmail.com Telp: (021) 741-2566 ke subyek pengabdian dengan cara memberikan pertanyaan langsung atau berbicara secara lisan dengan ketua komunitas Arimbi dilingkungan Desa Pondok Pucung Kecamatan Pondok Aren. Tangerang Selatan. Banten

Selain wawancara, tim PKM juga melakukan observasi yang merupakan kegiatan pengamatan langsung di lokasi. Observasi ini dilakukan langsung ke subyek dengan cara pengamatan di lingkungan.

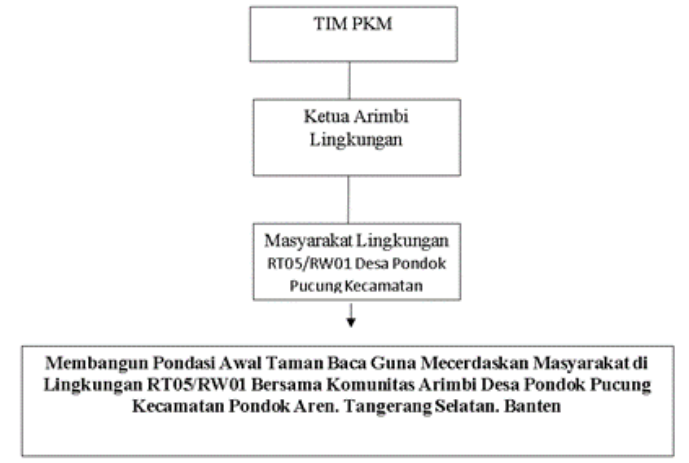

Metode yang akan digunakan dalam pengabdian masyarakat ini adalah melalui kegiatan pendampingan dan sosialisasi membangun taman baca dilingkungan Desa Pondok Pucung Kecamatan Pondok Aren. Tangerang Selatan. Banten

\section{KESIMPULAN DAN SARAN Kesimpulan}

Pembuatan taman baca ini merupakan salah satu alternatif untuk menjadi tempat pengembangan minat baca anak sejak dini, hasil observasi menunjukkan bahwa di , khususnya di Lingkungan RT05/RW01 Desa Pondok Pucung Kecamatan Pondok Aren tingkat kesadaran masyarakat akan pentingnya pendidikan dan minat baca anak sejak dini masih sangat kurang. Hal inilah yang menjadi acuan Tim PKM untuk mendirikan taman baca ini.

\section{Saran}

Saran kami untuk komunitas arimbi tetap melakukan monitoring di taman baca Lingkungan RT05/RW01 Desa Pondok Pucung Kecamatan Pondok Aren, terutama untuk masyarakat dilingkungan Rt05/Rw07 untuk selalu pengembangkan minat membaca khususnya anak usia dini.

\section{DAFTAR PUSTAKA}

Andi, D., Wiguna, M., Abid, M., Safiih, A. R., \& Imbron, I. (2020). Strategi Pengembangan Sdm Sebagai Persiapan Membangun Destinasi Wisata Curug Angkrek, Kp. Cimuncang, Desa Karangnunggal, Kabupaten Tasikmalaya. Dedikasi PKM, 2(1), 3337.

Deni Hendarto, Ahmad Muradin Putra, Evita Yulivina. 2018. Meningkatkan Kesadaran Masyarakat Akan Pentingnya Pendidikan di Desa Cihowe. Jurnal 2 (1).

Direktorat Pembinaan Pendidikan MasyarakatDirektorat Jenderal Pendidikan Anak Usia Dini, Nonformal, dan Informal, Kementrian Pendidikan dan Kebudayaan. 2012. Petunjuk Teknis Pengajuan dan Pengelolaan Taman Bacaan Masyarakat Tahun 2012. Jakarta.

Farida, S. I., Prasetiyani, D., Safiih, A. R., Prasada, D., \& Ismanto, B. (2020). Pelatihan SDM: Usaha Konvensional menjadi Usaha Digital. Jurnal Abdi Masyarakat Humanis, 1(2).

Farida, S. I., Zulkarnain, I., Safiih, A. R., Prasada, D., \& Oktavianti, N. (2020). Penyuluhan dan Berbagi Bersama untuk Guru Ngaji yang Terdampak Covid-19. Jurnal Abdi Masyarakat Humanis, 2(1).

Ludvy, A., Suhartono, A., Rukmana, I. J., \& Purnama, A. (2020). Penerapan Manajemen Berbasis Aktivitas Dalam Usaha Kecil Dan Menengah Di Kelurahan Paninggilan Utara Kecamatan Ciledug Kota Tangerang. Jurnal Lokabmas Kreatif: Loyalitas Kreatifitas Abdi Masyarakat Kreatif, $1(2), 82-87$.

Lestari, Gunarti Dwi dan Heryanto Susilo. 2014. Model Taman Bacaan Masyarakat (TBM) Kreatif: Upaya Melestarikan dan Memperkuat 


\section{JURNAL ABDIMAS

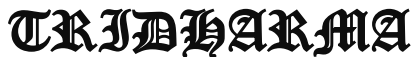 AtÃ}

Kemampuan Keaksaraan dan Usaha Mandiri. Edisi 8 Tahun 2011.JPNF.

Oktavianti, N., Nariah, N., Imbron, I., Safiih, A. R., \& Nuraldy, H. L. (2021). Pelatihan Jiwa Kepemimpinan Kepada Komunitas Pencinta Alam Kelurahan Pondok Pucung. Dedikasi PKM, 2(2), 181-187.

Pasaribu, V. L. D., Agrasadya, A., Shabrina, N., \& Krisnaldy, K. (2020). Menjadi Enterpreneur Muda Yang Memiliki Jiwa Leadership Untuk Menghadapi Masa Depan. Abdi Laksana: Jurnal Pengabdian Kepada Masyarakat, 1(1)

Pasaribu, V. L. D., Susanti, F., \& Hartuti, E. T. K. (2019). Memotivasi Siswa dan Siswi SMK Letris Indonesia di Dalam Menentukan Pilihan Untuk Melanjutkan Pendidikan Atau Bekerja Setelah Lulus Sekolah. Jurnal Pengabdian Dharma Laksana, 1(2), 161-172.

Pasaribu, V. L. D., Sulaiman, S., Sutiman, S., Thaharudin, T., \& Purnomo, B. Y. (2020). Pengenalan Letak Posyandu Terdekat Dikelurahan Pisangan Dengan Manajemen Pemasaran Revolusi 4.0 Untuk Meningkatkan Pengetahuan Masyarakat Letak Dan Fungsi Posyandu Terdekat Pada Kelurahan Pisangan. Dedikasi Pkm, 1(1), 105-110.

Pasaribu, V. L. D., Oktrima, B., Prabowo, B., Arianto, N., \& Haryoko, U. B. (2020). Progam Pendampingan Dan Penyelenggaraan Pendidikan Anak Pada Usia Dini Terhadap Prestasi Belajar Dilingkungan Rt 020 Rw 009. Kel Giri Peni. Kec Wates. Yogyakarta. Jurnal Lokabmas Kreatif, 1(1), 71-75.

Pasaribu, V. L. D., Jannah, M., Fazar, M., Putra, S. P., Monalisa, M., \& Sofa, M. (2021). MENINGKATKAN PRODUKTIVITAS USAHA DIMASA PANDEMI PADA IBU PKK RT 004/003 KELURAHAN SAWAH BARU CIPUTAT, TANGERANG SELATAN. Abdi
Laksana: Jurnal Pengabdian Kepada Masyarakat, 2(2), 295-301.

Pasaribu, V. L. D., Yuniati, H. L., Pranata, R., Sembayu, R., Purba, S. M., \& Nurbayani, T. T. A. (2021). MANAJEMEN KEUANGAN UNTUK MENGHADAPI DAN BERTAHAN DI ERA COVID 19. Jurnal Abdimas Tri Dharma Manajemen, 2(2), 12-18.

Pasaribu, V. L. D., Dwiyatni, A., Sabina, C., Ridwan, M., Gunawan, D. D., \& Noviani, B. C. (2021). EVALUASI PENERAPAN 3M DIMASA PANDEMIC COVID 19. Jurnal Abdimas Tri Dharma Manajemen, 2(2), 54-60.

Pasaribu, V. L. D., Syafei, A. N., Farhan, A., Aufaizah, A., Irani, C., \& Firtiayani, S. R. (2021). PENGARUH DISPLIN PROTOKOL KESEHATAN TERHADAP PENCEGAHAN PENULARAN VIRUS COVID19. Jurnal Abdimas Tri Dharma Manajemen, 2(2), 91-98.

Pasaribu, V. L. D., Septiani, F., Rahayu, S., Lismiatun, L., Arief, M., Juanda, A., ... \& Rahim, R. (2021). Forecast Analysis of Gross Regional Domestic Product based on the Linear Regression Algorithm Technique.

Priadi, A., Pasaribu, V. L. D., Virby, S., Sairin, S., \& Wardani, W. G. (2020). Penguatan Ekonomi Kreatif Berbasis Sumber Daya Desa Dikelurahan Rempoa. Abdi Laksana: Jurnal Pengabdian Kepada Masyarakat, 1(3), 356-35

Pasaribu, V. L. D., Priadi, A., Anismadiyah, V., Rahayu, S., \& Maduningtias, L. (2021). PENYULUHAN KREATIF DAN INOVATIF MENINGKATKAN MUTU PRODUKSI UMKM DI DESA BELEGA KABUPATEN GIANYAR. Pro Bono Jurnal Pengabdian Kepada Masyarakat, 1(02).

Pasaribu, V. L. D. (2021). PELATIHAN BERBASIS ONLINE DI ERA COVID-19. Jurnal Abdimas Tri 


\section{JURNAL ABDIMAS

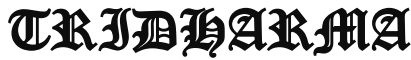 AtA:}

P-ISSN 2615-6849, E-ISSN 2716-070X

Jurnal ABDIMAS Vol.3,No.1,Desember 2021,Hal(105109)

@Prodi Manajemen Fakultas Ekonomi Universitas Pamulang

Email: abdimasjurnal.unpam@gmail.com Telp: (021) 741-2566

Dharma Manajemen, 2(3), 26-32.

Pasaribu, V. L. D., \& Setyowati, R. (2021). ADAPTASI KEHIDUPAN NEW NORMAL PADA MASA PANDEMI COVID-19 DIYAYASAN PONDOK PESANTREN DAN PANTI ASUHAN NURUL IKHSAN KECAMATAN SETU, KOTA TANGERANG SELATAN. Jurnal Lokabmas Kreatif: Loyalitas Kreatifitas Abdi Masyarakat Kreatif, 2(2), 82-88.

https://gurupengajar.com/permasalahanpendidikan-di-indonesia.html

https://gheroy.com/masalah-pendidikanyang-terjadi-di-indonesia/

https://www.akseleran.co.id/blog/permasal ahan-pendidikan-di-indonesia/

http://tbmnuruliman.blogspot.com/2014/03 tujuan-manfaat-fungsi-dan-perantaman.html

https://core.ac.uk/download/pdf/29628533 2.pdf

http://anastasyannisa.com/2019/01/18/ingi n-mendirikan-taman-bacaan-berikutbeberapa-tipsnya/

https://www.kompasiana.com/syarif1970/5 b51af3fab12ae381846acd5/tips-jitumendirikan-taman-bacaan-versi-tbmlentera-pustaka

\section{DOKUMENTASI KEGIATAN}
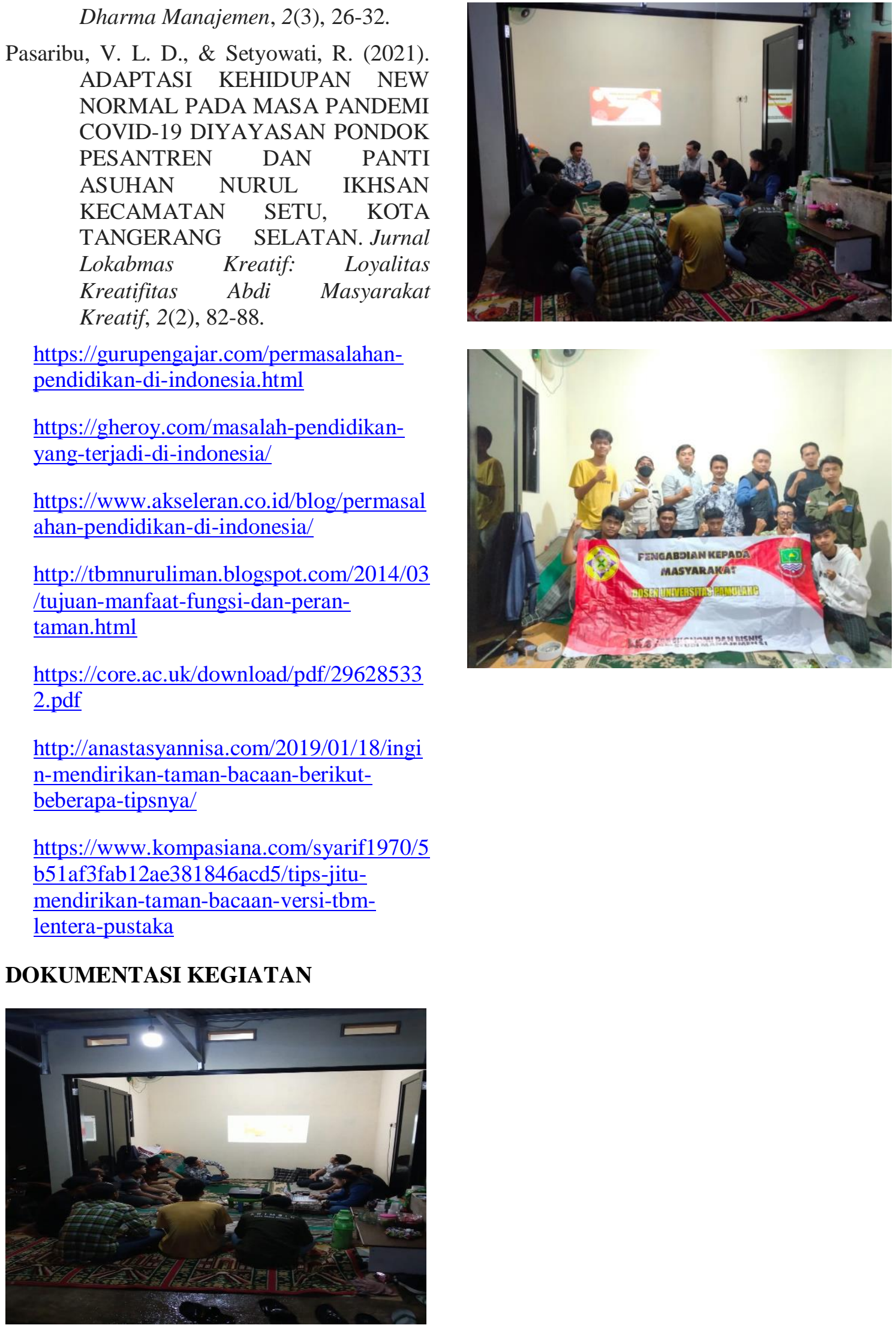